\title{
Pengaruh Substitusi Amtabis yang Difermentasi dengan Aspergillus Niger terhadap Performa Ayam Broiler
}

\author{
(The Effect of Substitution Fermented Amtabis with \\ Aspergillus Niger on Broiler Performance)
}

\author{
Muhammad Asril ${ }^{1}$, Yunasri Usman ${ }^{1}$ dan Samadi ${ }^{1}$ \\ ${ }^{1}$ Program Studi Peternakan, Fakultas Pertanian, Universitas Syiah Kuala
}

\begin{abstract}
Abstrak: Penelitian initelah dilakukan di Laboratorium Lapangan Peternakan Fakultas Pertanian Universitas Syiah Kuala yang berlokasi di Darussalam Banda Aceh sejaktanggal 4 Desember 2015 sampai dengan tanggal 9 Januari 2016. Tujuan penelitian adalah untuk mengetahui pengaruh subtitusi Amtabisterhadap performa ayam broiler yang meliputi pertambahan berat badan, konsumsi pakan dan feed conversion ratio. Parameter yang diamati meliputi konsumsi ransum, pertambahan berat badan, konversi ransum dan efisiensi ransum. Hasil penelitian menunjukkan bahwa substitusi Amtabis dalam ransum komersial pada level yang berbeda selama perlakuan berpengaruh nyata $(\mathrm{P}<0,05)$ terhadap pertambahan berat badan, namun tidak menunjukkan perbedaan yang nyata $(\mathrm{P}>0,05)$ terhadap konsumsi pakan, rasio konversi pakan dan efisiensi pakan.Terjadinya penurunan performa broiler dengan pemberian Amtabis kemungkinan disebabkan karena ketidak seimbangan kandungan nutrisi dalam ransum akibat penambahan Amtabis dalam pakan komersil.
\end{abstract}

Kata kunci: broiler, amtabis, performa dan substitutsi

Abstrack: Study on the effect of substitution fermented Amtabis with Aspergillus niger on broiler performance was conducted at Experimental Farm Laboratory, Animal Husbandry Department, Syiah Kuala University Darussalam Banda Aceh from 4 December 2015 to 9 January 2016. The purposes of this study was to evaluate substitution of fermented Amtabis with commercial broiler on broiler performance including body weight, feed consumption and feed conversion ratio. Parameters which were observed in this study were body weight, feed consumption and feed conversion ratio. The results on the study indicate that substitution of Amtabis in commercial feed significantly effected $(\mathrm{P}<0,05)$ on body weight, but had no significantly effect $(\mathrm{P}>0,05)$ on feed consumption, feed conversion ratio and feed efficiency.Decreasing of performance broiler by substitution Amtabis in the commercial feed was probably caused by imbalance of nutritive feed formulation after Amtabis substitution.

Keywords: broiler, amtabis, performance and substitution.

\section{PENDAHULUAN}

Kebutuhan masyarakat dalam mengkonsumsi protein hewani semakin meningkat seiring dengan bertambahnya jumlah penduduk dan kesadaran masyarakat akan kebutuhan gizi yang lebih baik. Salah satu sumber protein yang cukup diminati masyarakat adalah ayam broiler. Menurut Badan Pusat Statistik Republik Indonesia (2011), secara keseluruhanpada tahun 2010konsumsi daging asal ternak per kapita per tahun sebanyak $6953 \mathrm{~kg}$, mengalami kenaikan jika dibandingkan dengan konsumsi daging pada tahun 2009sebesar 6297 gr per kapita per tahun. Konsumsi ayam untuk Indonesia tahun 2011 sekitar 7 kg per kapita per tahun. 
Dalam suatu usaha peternakan, pakan memegang peranan yang sangat penting baik ditinjau dari segi produksi maupun dari segi ekonomi. Namunharga pakan yang sering berfluktuasi semakin menarik minat para peneliti untuk mencari bahan pakan alternatif yang bisa dimanfaatkan sebagai pakan ternak. Pakan alternatif tersebut tentu saja harus memenuhi kriteria-kriteria tertentu sehingga tidak menimbulkan efek negatif bagi pertumbuhan dan produksi ternak(Santoso, 2008).

Salah satu sumber bahan pakan yang dapat digunakan sebagai pakan ternak adalah bahan pakan yang berasal dari limbah industri pertanian. Bungkil inti sawit (BIS) adalah salah satu limbah industri pertanian yang dapat digunakan sebagai bahan pakan. Kandungan gizi bungkil inti sawit berdasarkan bahan kering adalah protein kasar 18,60\%, lemak 6,05\%, serat kasar 21,08\%, kalsium 0,34\%, dan fosfor 0,57\% (Nuraini, 2002). Disamping BIS, ampas tahu merupakan sumber pakan ternak yang belum digunakan secara maksimal selama ini. Menurut Rahayu (2012), ampas tahu basah dalam per 100 gram mengandung Karbohidrat 11,07\%, Protein 4,71\%, Lemak 1,94\% dan Abu 0,08\%.

Salah satu usaha untuk meningkatkan kualitas pakan adalah dengan teknologi fermentasi.Penelitian yang dilakukan oleh Nurliana et al. (2015) kombinasi antara BIS dan ampas tahu (Amtabis) yang difermentasi dengan Aspergillus niger (A.niger) menghasilkan kualitas pakan yang cukup baik. Amtabis berpotensi meningkatkandaya cerna dan efisiensi pakan unggas melalui peningkatan kinerja mikroflora ususmelalui penambahan A.niger.

\section{Tempat dan Waktu Penelitian}

\section{MATERI DAN METODE}

Penelitian ini dilaksanakan di Laboratorium Lapangan Peternakan Fakultas Pertanian Universitas Syiah Kuala yang berlokasi di Desa Kopelma Darussalam Banda Aceh sejaktanggal 4 Desember 2015 sampai dengan tanggal 9 Januari 2016.

\section{Materi Penelitian}

Materi yang digunakan dalam penelitian ini adalah 100 ekor day old chick (DOC) ayam broiler strain CP 707, produksi PT. Charoen Pokphand Jaya Farm, Medan. Amtabis (ampas tahu dan bungkil inti sawit), ransum komersial broiler (511 Bravo produksi PT. Charoen Pokphand), Vitastress, Vaksin Gumboro, Vaksin Newcastle Desease, A. niger.

\section{Peralatan Penelitian}

Peralatan yang digunakan dalam penelitian ini adalah kandang ayam dan perlengkapannya, antara lain: tempat pemberian ransum, tempat pemberian air minum, timbangan digital, terpal tempat mengaduk ransum, lampu pijar, kapur, label kandang, ember, thermometer, bukucatatan, alat tulis, lampu minyak, sprayer,kipas angin, serutan gergaji (litter) sebagai alas kandang.

\section{Ransum Penelitian}

Penelitian ini merupakan penelitian eksperimental yang menggunakan Rancangan Acak Lengkap (RAL). Menggunakan DOC sebanyak 100 ekor yang ditempatkan kedalam kandang percobaan yang dibagi secara acak menjadi 4 kelompok perlakuan dengan 5 pengulangan, satu pengulangan berisi 5 ekor ayam. 


\section{Pertambahan BeratBadan}

\section{HASIL DAN PEMBAHASAN}

Berdasarkan data pada Tabel 1 substitusi Amtabis pada pakan komersil berpengaruh nyata $(\mathrm{P}<0.05)$ terhadap pertambahan berat badan, dimana kontrol memperlihatkan hasil yang lebih baik dibandingkan dengan perlakuan. Penurunan pertambahan berat badan akibat pemberian Amtabis adalah sekitar 10\%. Penurunan pertambahan berat badan ternak dengan pemberian Amtabis kemungkinan keseimbangan pakan yang disusun yang tidak seimbang pada perlakuan penelitian. Pakan komersial sudah disusun dengan prinsip kebutuhan ternak, penambahan Amtabisakan menyebabkan keseimbangan bahan pakan terutama asam amino dan kandungan serat dalam pakan perlakuanterjadi perubahan.

Tabel 1. Rata-rata Pertambahan Berat Badan Ayam Broiler (rata-rata \pm SE) pada Umur Pemeliharaan 5 Minggu $(n=5)$

\begin{tabular}{cccc}
\hline Perlakuan & $\begin{array}{c}\text { Berat DOC } \\
\text { Awal }\end{array}$ & Berat Badan Akhir & Pertambahan Berat Badan $(\mathrm{g})$ \\
\hline P0 & 37,5 & 2233,4 & $2195,9^{\mathrm{a}} \pm 37,9$ \\
P1 & 37,5 & 1998,1 & $1960,6^{\mathrm{b}} \pm 62,8$ \\
P2 & 37,5 & 1994,5 & $1957,0^{\mathrm{b}} \pm 28,8$ \\
P3 & 37,5 & 2030,9 & $1993,4^{\mathrm{b}} \pm 33,2$ \\
\hline
\end{tabular}

ab Superscript yang berbeda pada baris yang sama menunjukkan perbedaan yang sangat nyata $(\mathrm{P}<0,01) . \mathrm{P} 0=$ $100 \%$ pakan komersial $+0 \%$ Amtabis, $\mathrm{P} 1=98 \%$ pakan komersial $+2 \%$ Amtabis, $\mathrm{P} 2=96 \%$ pakan komersial $+4 \%$ Amtabis, $\mathrm{P} 3=94 \%$ pakan komersial $+6 \%$ Amtabis .

Penelitian yang dilakukan oleh Samadi dan Liebert (2007a,b, dan 2008) keseimbangan asam amino dalam pakan akan mempengaruhi pertumbuhan ayam broiler. Disamping itu, dalam penelitian tersebut dikemukan bahwa kebutuhan asam amino esensial dipengaruhi oleh jenis kelamin dan tingkatan pertumbuhan dari ternak. Namun keseimbangan asam amino dalam penelitian ini tidak dihitung.Demikian juga kandungan serat yang tinggi dalam suatu bahan pakan mempengaruhi performa ternak (Walugembe, 2012).

Dalam penelitian ini dengan adanya pertambahan Amtabis diperkirakan dapat meningkatkan kandungan serat kasar dalam pakan karena jumlah serat kasar pada BIS dan ampas tahu yang cukup tinggi. Kandungan serat kasar pada BIS sebanyak 21,08\%, kalsium 0,34\%, dan fosfor 0,57\% (Nuraini, 2002). Menurut Rahayu (2012), Kandunganserat kasar pada ampas tahu sebanyak $16,53 \%$.

Rail (2007) menyatakan bahwa, faktor yang mempengaruhi pertambahan berat badan yaitu faktor lingkungan dan faktor genetik.Faktor lingkungan yang paling berperan adalah faktor pakan yang diberikan, baik itu kualitas maupun kuantitasnya, kondisi pemeliharaan, kesehatan serta manajemen pemeliharaan. Menurut Gordon (2002), terdapat perbedaan berat badan antara ternak yang diberikan ransum ad libitum dan ternak yang ransumnya dibatasi serta perbedaan antara ternak yang mendapat rasio ransum yang optimal dan ternak yang mendapat ransum tidak optimal.

\section{Konsumsi Ransum}

Konsumsi ransum ayambroiler dengan pemberian pakan komersil yang disubtitusi dengan Amtabis dapat dilihat pada Tabel 2. Berdasarkan data pada Tabel 2 substitusi Amtabis pada pakan komersil tidakmenunjukkanperbedaan yang nyata $(\mathrm{P}>0,05)$ terhadap tinggi konsumsi ransum, dimana kontrol memperlihatkan hasil yang lebih baik dibandingkan dengan perlakuan. 
Tabel 2. Rata-rata Konsumsi Ransum Ayam Broiler (rata-rata \pm SE) pada UmurPemeliharaan 5 Minggu $(\mathrm{n}=5)$

\begin{tabular}{cc}
\hline Perlakuan & Konsumsi (g) \\
\hline P0 & $3435,5 \pm 156,0$ \\
P1 & $3288,9 \pm 147,6$ \\
P2 & $3252,1 \pm 11,7$ \\
P3 & $3264,6 \pm 118,4$ \\
\hline
\end{tabular}

Ket : $\mathrm{P} 0=100 \%$ pakan komersial $+0 \%$ Amtabis, $\mathrm{P} 1=98 \%$ pakan komersial $+2 \%$ Amtabis, $\mathrm{P} 2=96 \%$ pakan komersial $+4 \%$ Amtabis, $\mathrm{P} 3=94 \%$ pakan komersial $+6 \%$ Amtabis.

Walaupun secara statistik hasil yang diperoleh tidak berbeda nyata namun pada pemberian Amtabis cenderung menurunkan konsumsi ransum. Hal ini disebabkan karena faktor penambahanpakan Amtabis yang berpengaruh seperti kandungan energi, serat kasar, palatabilitas, lemak kasar, bentuk fisik ransum, aroma, dan warna. Palatabilitas merupakan faktor yang sangat penting untuk menentukan tingkat konsumsi pakan, dimana palatabilitas pakan ditentukan oleh rasa, bau dan warna yang merupakan pengaruh faktor fisik dan kimia pakan. Menurut Afrianti (2002), pemberian ransum atau pakan disamping harus memenuhi zat-zat nutrisi yang dibutuhkan dengan jumlah yang tepat, pakan tersebut harus memenuhi syarat-syarat seperti aman untuk dikonsumsi, palatabel ekonomis dan berkadar gizi yang cukup untuk memenuhi kebutuhan ternak.

Seperti halnya hasil penelitian Nurhayati (2007), menunjukkan bahwa tidak ada interaksi antara level produk fermentasi, pemberian kunyit, dan pemberian vaksin terhadap konsumsi pakan. Hasil penelitian juga menunjukkan bahwa masing-masing faktor tidak berpengaruh nyata $(\mathrm{P}>0,05)$ terhadap konsumsi pakan. Sesuaidengan Amrullah (2004) mengemukakan bahwa, kandungan energi ransum sangat memengaruhi jumlah konsumsi ransum, semakin tinggi energi ransum semakin rendah konsumsi ransum, dan faktor yang juga memengaruhi jumlah konsumsi ransum adalah ternak, lingkungan fisik, dan pakan.

\section{Konversi Ransum}

Konversi ransum merupakan salah satu standartyang dapatdigunakan sebagai pedoman untuk mengetahui efisiensipenggunaan pakan oleh ternak.Semakin rendah angkakonversi ransum,maka semakin tinggi keberhasilanpemeliharaanayam pedaging. Semakin rendahnilaikonversiransum berarti kualitasransum semakinbaik.Demikian sebaliknya semakin tingginilaikonversi ransum menunjukkan semakin banyak ransum yangdibutuhkan untuk meningkatkanberatbadanper satuan berat (Daud, 2009). Rata-rata konversi ransum pada penelitian ini dapat dilihat pada Tabel 3.

Tabel 3. Rata-rata Konversi Ransum Ayam Broiler (rata-rata \pm SE) pada UmurPemeliharaan 5 Minggu ( $\mathrm{n}=5)$

\begin{tabular}{cc}
\hline Perlakuan & Konversi Ransum \\
\hline P0 & $1,6 \pm 0,1$ \\
P1 & $1,7 \pm 0,1$ \\
P2 & $1,7 \pm 0,1$ \\
P3 & $1,6 \pm 0,1$
\end{tabular}

Ket $: \quad \mathrm{P} 0=100 \%$ pakan komersial $+0 \%$ Amtabis, $\mathrm{P} 1=98 \%$ pakan komersial $+2 \%$ Amtabis, $\mathrm{P} 2=96 \%$ pakan komersial $+4 \%$ Amtabis, $\mathrm{P} 3=94 \%$ pakan komersial $+6 \%$ Amtabis.

Hasil analisis sidik ragam pada perlakuan tingkat substitusi Amtabis dalam ransum komersial menunjukkantidak berbeda nyata $(\mathrm{P}>0,05)$ terhadap tingkat konversi ransum. Dari Tabel 3. dapat dilihat bahwa, korvensi ransum yangtertinggi terdapat pada perlakuan P1 (2\% Amtabis) dan P2 (4\% Amtabis) yaitu 1,7, diikuti dengan perlakuan P0 (0\% Amtabis) dan P3 
(6\% Amtabis) yaitu 1,6. Seperti halnya pada penelitian Nurhayati (2007), hasil analisis ragam menunjukkan bahwa tidak ada interaksi antara level produk fermentasi dan kunyit dalam pakan, dan pemberian vaksin terhadap konversi pakan.

Wahju (1997) menyatakan bahwa angka konversi ransum yangsemakinmeningkat membuktikan ransumsemakin tidak efisien. Namun pada penelitian ini angka konversi ransum semakin menurun dengan penambahan Amtabis yang semakin meningkat. Konversi pakan ayam broiler strain CP 707 yang dipelihara pada suhu nyaman pada umur lima 5 minggu adalah 1,62 .

\section{Efisiensi Ransum}

Hasil analisissidik ragam pada perlakuan tingkat substitusi Amtabis dalamransum komersial menunjukkan tidak berpengaruh nyata $(\mathrm{P}>0,05)$ terhadap tingkat efisiensi ransum. Rata-rata efisiensi ransumpada berbagai tingkat pemberian Amtabis dapat dilihat pada Tabel 4.

Tabel 4. Rata-rata Efisiensi Ransum Ayam Broiler (rata-rata \pm SE) pada UmurPemeliharaan 5 Minggu ( $\mathrm{n}=5)$

\begin{tabular}{cc}
\hline Perlakuan & Efisiensi Ransum (\%) \\
\hline P0 & $64,7 \pm 4,4$ \\
P1 & $59,9 \pm 2,3$ \\
P2 & $60,4 \pm 2,2$ \\
P3 & $62,4 \pm 1,8$ \\
\hline
\end{tabular}

Ket : $\mathrm{P} 0=100 \%$ pakan komersial $+0 \%$ Amtabis, $\mathrm{P} 1=98 \%$ pakan komersial $+2 \%$ Amtabis, $\mathrm{P} 2=96 \%$ pakan komersial $+4 \%$ Amtabis, $\mathrm{P} 3=94 \%$ pakan komersial $+6 \%$ Amtabis.

Perbedaan penambahan Amtabisdalam ransum komersial tidak berpengaruh nyata $(\mathrm{P}>0,05)$ terhadap efisiensi ransum ayam broiler. Hasil penelitian dapat dilihat bahwa pada penggunaan Amtabis 2\% (P1) dan 4\% (P2) efisiensi ransum semakin menurun dan pada perlakuan P3 (6\% Amtabis) mengalami peningkatan. Hal ini berkaitan dengan konversi ransum, semakin besar nilai konversi ransum maka semakin kecil nilai efisiensinya dan sebaliknya semakin kecil nilai konversi ransum maka semakin besar nilai efisiensinya.

\section{KESIMPULAN}

Dari penelitian ini dapat disimpulkan bahwa pemberian Amtabis sebagai bahan pakan substitusi pada ransum pakan komersil berpengaruh nyata $(\mathrm{P}<0,05)$ terhadap pertambahan berat badan, namun tidak menunjukkan perbedaan yang nyata $(\mathrm{P}>0,05)$ terhadap konsumsi pakan, rasio konversi pakan dan efisiensi pakan. Dalam penelitian ini, terjadinya penurunan berat badan broiler padaperlakuan substitusi Amtabisdengan pakan komersil. Penurunan berat badan broiler, kemungkinan disebabkan karena ketidak seimbangan kandungan nutrisi dalam ransum akibat penambahan Amtabis dalam pakan komersil terutama kandungan asam amino. Namun dalam penelitian ini, kandungan asam amino Amtabis tidak dianalisa sebelum pakan diformulasi. Disamping itu, kandungan serat kasar ransum yang kemungkinan berpengaruh dengan adanya substitusi Amtabis dalam pakan komersil dan mengakibatkan terjadinya penurunan daya cerna sehingga berakibat kepada pertumbuhan ternak. 


\section{DAFTAR PUSTAKA}

Afrianti, L.H. 2002. Pati Termodifikasi Dibutuhkan Industri Makanan. Pikiran Rakyat Cyber Media. Hal: 28-32.

Amrullah, I.K. 2004. Nutrisi ayam Broiler.Lembaga satu Gunung Budi, Bogor.

Badan Pusat Statistik Republik Indonesia. 2011. Buletin Statistik Perdagangan Luar Negeri Impor. Jakarta: Badan Pusat Statistik.

Daud, M., W. G Piliang., K. G Wiryawan dan A. Setiyono. 2009. Penggunaan Prebiotik Oligosakarida Ekstrak Tepung Buah Rumbia (Metroxylon sago Rottb.) dalam Ransum terhadap Performan Ayam Pedaging. Agripet : Vol (9) No. 2: 15-20

Gordon, S.H. and D.R. Charles. 2002. Niche and Organic Chicken Products: Their

Technology and Scientific Principles. Nottingham University Press,Definitions: III-X, UK.

Nuraini. 2002. Pengaruh penggunaan bungkil inti sawit dalam ransum ayam broiler. Laporan Penelitian. Fakultas Perternakan Unand Padang.

Nurhayati. 2007. Pengaruh Tingkat Penggunaan Campuran Bungkil Inti Sawit dan Onggok Terfermentasi oleh Aspergillus niger dalam Pakan terhadap Penampilan Ayam Pedaging. Jurnal Pengembangan Peternakan Tropis vol.32, No.1: 28-32.

Nurliana, S. Wajizah. Dan D. Masyitha. 2015. Laporan Kemajuan Penelitian Hibah Bersaing. Universitas Syiah Kuala, Banda Aceh.

Rahayu, W.P. 2012. Penuntun Praktikum Penilaian Organoleptik. Fakultas Teknologi Pertanian IPB, Bogor.

Rail, R. 2007. Tumbuh kembang bagian-bagian karkas ayam broiler pada jenis kelamin dan tingkat umur yang berbeda. Skripsi Sarjana. Fakultas Peternakan, Universitas Haluoleo, Kendari.

Samadi, and F. Liebert. 2007a. Lysine requirement of fast growingchickens-Effect of age, sex, level of protein deposition and dietarylysine efficiency. Jpn. Poult. Sci. 44:63-72.

Samadi, and F. Liebert. 2007b. Threonine requirement of slow growingmale chickens depends on age and dietary efficiency of threonineutilization. Poult. Sci. 86:11401148.

Samadi, and F. Liebert. 2008. Modelling the optimal lysine to threonineratio in growing chickens depending on age and efficiency ofdietary amino acid utilization. Br. Poult. Sci. 49:45-54.

Santoso.2008.Pengaruh Penambahan Ekstrak Daun Katuk Terhadap Kualitas Telur dan Berat Organ Dalam. Jurusan Peternakan, Fakultas Pertanian, Universitas Bengkulu, BesngkuluJalan Raya Kandang Limun, Bengkulu.

Walugembe, M. 2012. The Effects of High and Low Dietary Fibers Diets on the Performance of Two Lines of Chickens with Divergent Growth Rates. Disertasi, Iowa State University 